\title{
Sexual dimorphism for growth in Muscovy ducks and changes in insulin-like growth factor I (IGF-I), growth hormone (GH) and triiodothyronine (T3) plasma levels
}

\author{
Elisabeth BAÉZA*, John WiLliAMS, Daniel GuÉMENÉ, \\ Michel J. DuClOS
}

Station de Recherches Avicoles, INRA, 37380 Nouzilly, France

(Received 8 December 2000; accepted 12 February 2001)

\begin{abstract}
Muscovy ducks display marked sexual dimorphism for body weight. The aim of our study was to analyse the possible relationships between this dimorphism and plasma levels of T3, GH and IGF-I from hatch to 15 weeks of age. We found no significant effect of sex or age on plasma T3 which remained relatively stable about $6 \mathrm{nM} \cdot \mathrm{L}^{-1}$. Plasma GH levels were highest $\left(14-24 \mathrm{ng} \cdot \mathrm{mL}^{-1}\right)$ but highly variable during the first four weeks in females and during the first seven weeks in males. Then, they decreased and remained low $\left(3-4 \mathrm{ng} \cdot \mathrm{mL}^{-1}\right)$ until the age of 15 weeks. A trend for higher GH concentrations in males compared to females was observed across the experimental period. The difference was maximum around 6-7 weeks of age. Plasma IGF-I levels rose sharply between 2 and 3 weeks of age and remained high until 6-7 weeks of age for the females and 13 weeks of age for the males then started to decrease. For the whole experimental period, significantly higher IGF-I levels were measured in males. The differences between sexes were significant between 7 and 12 weeks of age and at 14 weeks of age. The differences in circulating GH and IGF-I levels between sexes suggest that the somatotrophic axis is implicated in Muscovy duck sexual dimorphism.
\end{abstract}

sex / dimorphism / GH / IGF-I / T3 / duck

Résumé - Dimorphisme sexuel du canard de Barbarie et variation des concentrations plasmatiques en IGF-I, GH et T3. Le canard de Barbarie présente un dimorphisme sexuel sur le poids vif assez prononcé. L'objectif de la présente étude était d'analyser les relations éventuelles entre ce dimorphisme et les concentrations plasmatiques de T3, GH et IGF-I depuis l'éclosion jusqu'à l'âge de 15 semaines. Aucun effet significatif du sexe ou de l'âge n'est mis en évidence sur le taux circulant de T3 qui reste stable à environ $6 \mathrm{nM} \cdot \mathrm{L}^{-1}$. Le taux circulant de $\mathrm{GH}$ est très élevé et très variable au cours des quatre premières semaines chez les femelles et des sept premières semaines chez les mâles. Il décroît ensuite pour atteindre $3-4 \mathrm{ng} \cdot \mathrm{mL}^{-1}$ à partir de $9-10$ semaines jusqu'à l'âge de 15 semaines. Sur l'ensemble de la période expérimentale, les mâles présentent un taux circulant de GH significativement

* Correspondence and reprints

E-mail: baeza@tours.inra.fr 
plus élevé que les femelles. Cette différence est maximale à l'âge de 6-7 semaines. La concentration plasmatique d'IGF-I s'accroît fortement à partir de l'âge de 2-3 semaines et reste élevée jusqu'à l'âge de 6-7 semaines pour les femelles et de 13 semaines pour les mâles. Puis, ce taux décroît avec l'âge. Sur l'ensemble de la période expérimentale, les mâles présentent un taux circulant d'IGF-I significativement plus élevé que les femelles. Les différences entre les deux sexes sont significatives entre 7 et 12 semaines et à 14 semaines. Les différences de concentrations plasmatiques en GH et IGF-I observées entre mâles et femelles suggèrent que l'axe somatotrope est impliqué dans le dimorphisme sexuel du canard de Barbarie.

sexe / dimorphisme / GH / IGF-I / T3 / canard

\section{INTRODUCTION}

Sexual dimorphism for body weight is observed in almost all domesticated avian species. However, the degree of divergence between sexes varies considerably between species. In the Pekin duck, the difference is small: $3.5 \%$ [18]. In contrast, in Muscovies, the drake is almost twice the size of the female [18]. Moreover, selection for increased body weight reinforced this sexual dimorphism [18].

In the Muscovy duck, the difference in body weight becomes apparent from 3 weeks of age and increases at a constant rate [15]. Consequently, males and females have to be reared separately. After slaughter, males are marketed as cut and deboned products, while females are sold, as whole carcasses. Another important characteristic is the difference of growth rate with age between sexes. Growth rate is maximum at $30 \mathrm{~d}$ of age for the female and $35 \mathrm{~d}$ of age for the male [15]. Growth of breast muscle occurs after growth of thigh muscles and is still high for the male after 10 weeks of age [15]. This explains the difference of slaughter ages: 10 weeks for the female and 12 weeks for the male.

Many endocrine factors interact to regulate avian growth and development [8]. Thyroid hormones (triiodothyronine, $\mathrm{T} 3$ and thyroxine, T4), growth hormone (GH) and insulin-like growth factors (IGF-I and -II) are considered the main regulators. A decrease of T3 plasma level with age has been reported in several species of birds [22]. Higher or equal T3 concentrations have been observed in male compared to female chickens $[19,22]$ while no difference was recorded in turkeys [6]. GH concentrations are highest in the early period of rapid growth $[13,21]$, then decline to low levels prior and through sexual maturation into adulthood [21]. GH secretion is pulsatile in chickens [23] and turkeys [1], and it has been shown that males exhibited higher peak frequency, peak amplitude and baseline concentrations than females. With age, the decrease of these variables occurred earlier for the females [1, 23]. A good part of the effect of $\mathrm{GH}$ is believed to be mediated by the somatomedin IGF-I. In birds, IGF-I concentrations rise steadily during post-hatch growth to reach a maximum (around 6 weeks of age in the chicken) then slowly decline to relatively low levels in adults [21]. Inconsistent results have been reported when comparing male and female for IGF-I in different bird species. Lower concentrations of IGF-I were observed in male than female chickens at early ages (first 3 weeks posthatch), while no difference occurred at later ages [14]. Higher IGF-I concentrations were described in male compared to female growing turkeys [2] and Pekin ducks [9]. Then, the aim of our study was to investigate the effects of sex and age on the circulating concentrations of T3, GH and IGF-I in male and female Muscovy ducks from 1-d old to 15 weeks of age. 


\section{MATERIALS AND METHODS}

\subsection{Bird management}

Male and female Muscovy ducks ( $n=100$ per sex), line R51 (Grimaud, Roussay, France), were reared separately on slats under red light (5 lux) with a day length of 12 hours and controlled temperature of $20{ }^{\circ} \mathrm{C}$. All ducks received a growing diet (12.54 MJ ME $\cdot \mathrm{kg}^{-1}$ and $190 \mathrm{~g} \mathrm{CP} \cdot \mathrm{kg}^{-1}$ ) between 0 and 8 weeks of age and a finishing diet (12.74 MJ ME. $\mathrm{kg}^{-1}$ and $160 \mathrm{~g}$ $\mathrm{CP} \cdot \mathrm{kg}^{-1}$ ) between 9 and 15 weeks of age. From $1 \mathrm{~d}$ to 15 weeks of age, blood samples were collected weekly from 10 males and 10 females chosen at random, in heparinised tubes and kept on ice. After centrifugation, plasma were separated, aliquoted and stored at $-18{ }^{\circ} \mathrm{C}$ until assayed for hormone measurements. Every fortnight, the animals were weighed.

\subsection{T3, GH \\ and IGF-I radioimmunoassays}

Plasma concentrations of T3 were determined by radioimmunoassay as described by Gabarrou et al. [11].

Plasma concentrations of $\mathrm{GH}$ were determined using an heterologous radioimmunoassay using chicken GH according Proudman and Wentworth [16].
IGF-I was extracted from plasma following acidification and ultrafiltration using centricon 30 membranes (Amicon, Millipore Company, Saint-Quentin-en-Yvelines, France) and assayed by heterologous radioimmunoassay as validated previously in the chicken [5]. The absence of contaminating IGF binding protein activity was confirmed in each individual extract. As a further validation of the procedure, it was verified that similar yields of IGF-I immunoreactivity were extracted from increasing values of plasma $(25$ or $50 \mu \mathrm{L})$ from birds of different ages (1 day, 2, 4, 6, 8, 10, 12 and 15 weeks). Moreover, serial dilutions of the extracted samples fitted a curve parallel to the human IGF-I standard curve as illustrated in Figure 1 for 1 day and 8 week old duck samples. For the comparison between sexes the extraction was performed on $50 \mu \mathrm{L}$ of plasma and the IGF-I concentration was determined on $1.25 \mu \mathrm{L}$ plasma equivalent in triplicate.

For each hormone, all samples were processed in the same assay.

\subsection{Statistical analysis}

Analyses were carried out by analysis of variance using the General Linear Model procedure of SAS [17]. The model included the main effects of sex and age and their interaction. Before analysis of the plasma hormone concentrations, the raw data were
Figure 1. Competitive inhibition of the binding of ${ }^{125}$ I-labelled human recombinant insulin-like growth factor-I to the IGF-I antibody by serial dilutions of duck plasma extracts. The last were prepared from 25 (open symbols) or $50 \mu \mathrm{L}$ (closed symbols) of plasma from 1 day (square) or 8 week old (triangle) ducks. Results are mean of triplicate determinations.

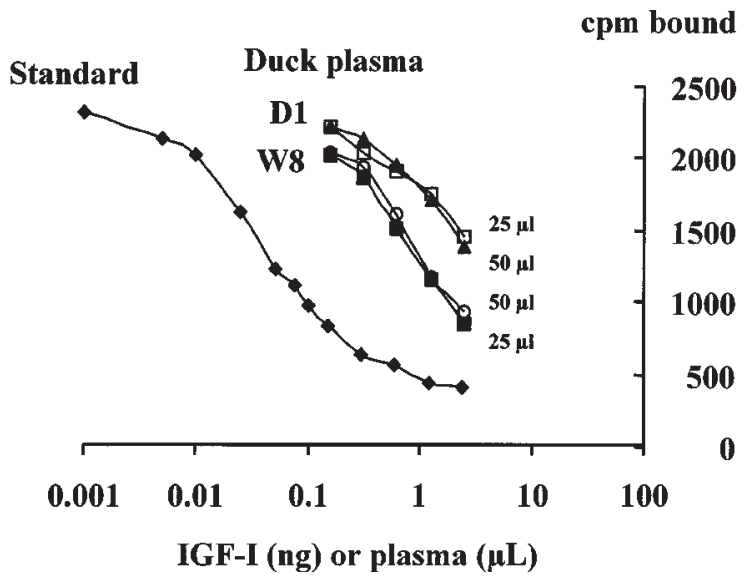




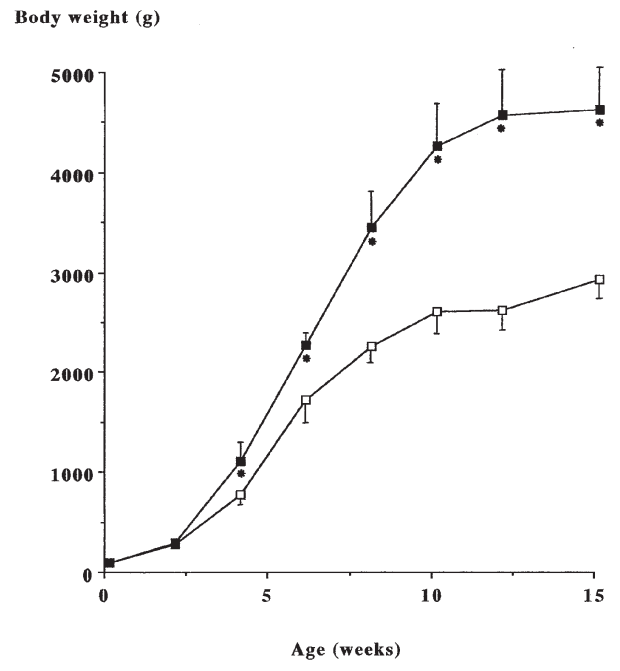

Figure 2. Growth curves of male (closed symbols) and female (open symbols) Muscovy ducks Data are mean \pm standard deviation $(n=10)$. Significantly different means between sexes $(P<0.01)$ are indicated by *.

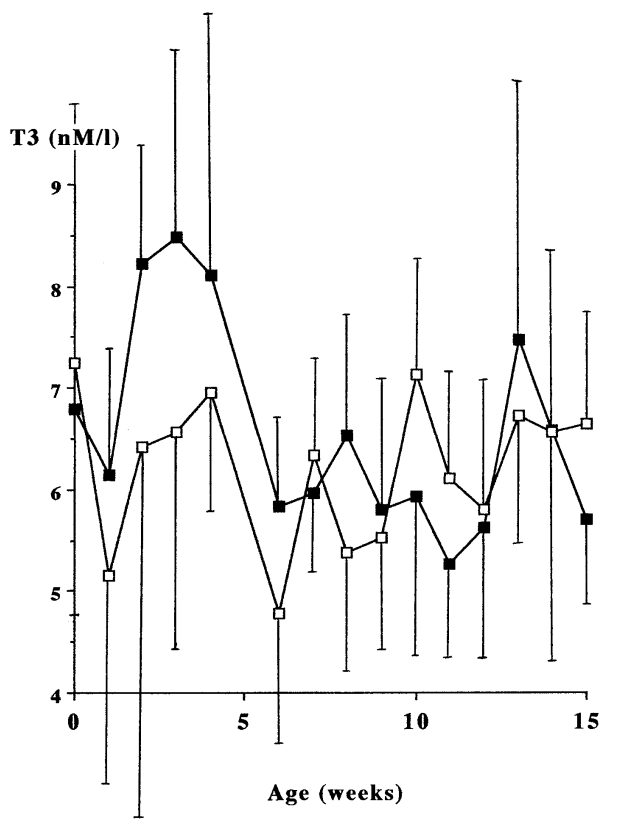

Figure 3. Variation with age of plasma triiodothyronine (T3) for male (closed symbols) and female (open symbols) Muscovy ducks. Data are mean \pm standard deviation $(n=10)$. transformed with a common logarithm $\left(\log 10^{\mathrm{x}}\right)$ to obtain a normal distribution of the values.

\section{RESULTS}

\subsection{Growth of ducks}

Mean body weights of males and females were similar at hatch (about $45 \mathrm{~g}$ ), then became significantly higher in males from 4 weeks of age $(P<0.01)$ and reached $4,573+408 \mathrm{~g}$ and $2,879 \pm 210 \mathrm{~g}$ respectively, at 15 weeks of age (Fig. 2).

\subsection{Plasma T3 levels}

Mean plasma T3 levels varied between 5 and $7 \mathrm{nM} \cdot \mathrm{L}^{-1}$ for the females and between 5 and $8 \mathrm{nM} \cdot \mathrm{L}^{-1}$ for the males (Fig. 3). The coefficient of variation were high and comprised between 14 and $31 \%$ for both sexes. At 2, 3 and 4 weeks of age, males presented higher plasma $\mathrm{T} 3$ levels but the differences with females were not significant (Fig. 3). No significant effect of age or sex could be demonstrated.

\subsection{Plasma GH levels}

Mean plasma GH levels were the highest during the first four weeks in females and during the first seven weeks in males (Fig. 4). Then, they decreased sharply to remain at low levels from 9 weeks of age (Fig. 4). The standard error of values was high for both sexes until 9 weeks of age. For the whole experimental period, the males presented significantly $(P<0.01)$ higher GH levels than females. This difference was maximum at 6 and 7 weeks of age (Fig. 4).

\subsection{Plasma IGF-I levels}

Mean plasma IGF-I levels rose gradually until 3 weeks of age in both sexes (Fig. 5). 
They remained high until 6-7 weeks of age in females, then decreased rapidly (Fig. 5). By contrast, they remained high in males until 13 weeks of age, then started to decrease. For the whole experimental period, the males presented significantly $(P<0.05)$ higher IGF-I levels than females. The differences between sexes were significant between 7 and 12 weeks of age and at 14 weeks of age (Fig. 5).

\section{DISCUSSION}

Our study confirmed previous results [15] on the sexual dimorphism of Muscovy ducks and its marked effect on body weight. We also confirmed the difference in growth rate between sexes, females displaying earlier body and muscular development [3, 4]. Therefore, Muscovy duck is an interesting model to study endocrine regulation of sexual dimorphism on body weight.

In the present study, we found no significant effect of sex and age for plasma T3 levels. Similarly, in white Leghorn chickens, Scanes et al. [18] found no significant effect of sex or age (from 1 day to 20 weeks of age) on plasma T3 concentrations. In turkeys, Burke et al. [6] found no differences between sexes for this hormone. On the other hand, Stewart et al. [22] observed that plasma T3 level in chickens, increased from 3 to 14 days of age and then decreased. Males had higher T3 levels than did females. These contradictory results suggest little role of T3 in the determinism of sexual dimorphism.

Changes in plasma GH levels have been previously reported in ducks. In mallard ducklings sacrificed at 2 weeks of age, Capdevielle and Scanes [7] found levels reaching between 97 and $119 \mathrm{ng} \cdot \mathrm{mL}^{-1}$. In male Pekin ducks, Foltzer et al. [10] described a gradual decrease in plasma $\mathrm{GH}$ levels from $50 \mathrm{ng} \cdot \mathrm{mL}^{-1}$ to $10 \mathrm{ng} \cdot \mathrm{mL}^{-1}$ between 1 and 9 weeks of age. In Pekin ducks, Scanes et al. [20] showed that the

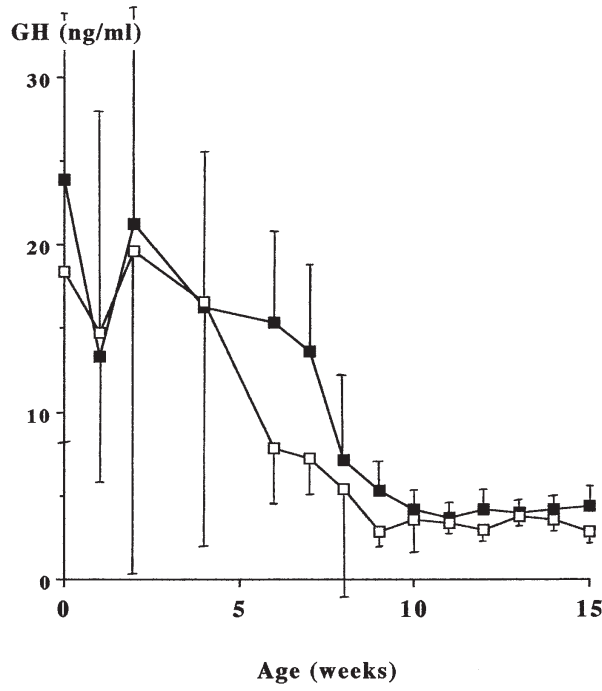

Figure 4. Variation with age of plasma growth hormone $(\mathrm{GH})$ for male (closed symbols) and female (open symbols) Muscovy ducks. Data are mean \pm standard deviation $(n=10)$.

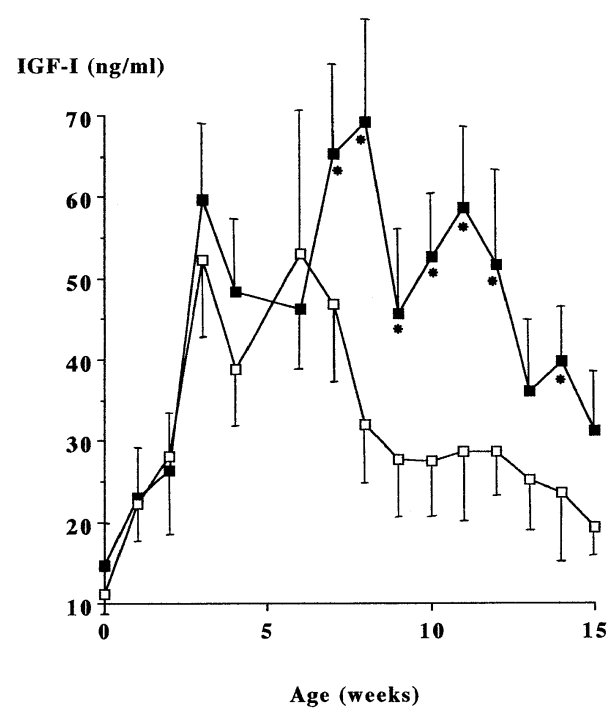

Figure 5. Variation with age of plasma insulinlike growth factor-I (IGF-I) for male (closed symbols) and female (open symbols) Muscovy ducks. Data are mean \pm standard deviation $(n=10)$. Significantly different means between sexes $(P<0.05)$ are indicated by *. 
decrease of plasma GH levels occurred earlier in females. In Muscovy ducks, a trend for higher $\mathrm{GH}$ concentrations in males compared to females was observed across the experimental period. (Fig. 4). The data also suggested that $\mathrm{GH}$ concentrations decreased earlier in females (about 4 weeks of age) than in males (about 7 weeks of age) as observed previously in Pekin ducks [20], chickens [23] and turkeys [1]. In birds [20] and mammals [12], higher variable levels of GH observed in young compared to older animals and in males compared to females were related with pulsatile $\mathrm{GH}$ secretion of higher frequency and amplitude. A similar mode of secretion is suggested in Muscovy ducks by the very large coefficient of variation observed in our data until 8 weeks of age.

IGF-I is under the control of GH and is believed to mediate part of its effect on growth [20,21]. Its concentration was measured for the first time in the Muscovy duck. We present evidence that the extraction procedure and the heterologous IGF-I RIA previously validated in the chicken [5] provide reliable estimates of IGF-I variations in this species. In our study, plasma IGF-I concentrations increased until 3 weeks of age, remained high for a few weeks, when growth rate of Muscovy ducks was maximum, then decreased as observed in chickens, turkeys [21] and Pekin ducks [9]. The decline with age occurred later in males than females (13 weeks vs. 8 weeks) and also later than in Pekin ducks (about 6-7 weeks of age) which display faster growth rate [9]. This difference induced higher circulating IGF-I levels in males than in females between 7 and 12 weeks of age, which is consistent with the results obtained in Pekin ducks [9] and turkeys [2]. By contrast, male chickens have been reported to have lower concentrations of IGF-I than females at early ages (first 3 weeks post-hatch), and not to differ from females at later ages [14]. The differences in GH and IGF-I observed in the present study is consistent with the higher growth rate, the higher osseous
[Leterrier, personal communication] and lean tissue deposition in males, particularly the breasts [4]. The decrease in IGF-I plasma levels occurring earlier and faster for the females is consistent with their earlier body development [4]. Therefore, GH and IGF-I seemed to be associated with Muscovy duck dimorphism. It remains to be investigated if these changes are causally related.

\section{ACKNOWLEDGEMENTS}

We are very grateful to M. Mills, M.T. Durand and B. Chevalier for their technical assistance and to O. Callut and C. Moisy for duck breeding. We acknowledge Dr. Proudman (Beltsville Agricultural Research Centre, USA) for providing the reference chicken $\mathrm{GH}$ and specific cGH antibody and Drs Märki and Kaufman (Ciba-Geigy, Basle, Switzerland) for the gift of recombinant human IGF-I.

\section{REFERENCES}

[1] Bacon W.L., Vasilatos-Younken R., Nestor K.E., Andersen B.J., Long D.W., Pulsatile patterns of plasma growth hormone in turkeys: effects of growth rate, age and sex, Gen. Comp. Endocrinol. 75 (1989) 417-426.

[2] Bacon W.L., Nestor K.E., Emmerson D.A Vasilatos-Younken R., Long D.W., Circulating IGF-I in plasma of growing male and female turkeys of medium and heavy weight lines, Domest. Anim. Endocrinol. 10 (1993) 267-277.

[3] Baéza E., Salichon M.R., Marché G., Juin H. Effect of sex on growth, technological and organoleptic characteristics of the Muscovy duck breast muscle, Br. Poult. Sci. 39 (1998) 398-403.

[4] Baéza E., Marché G., Wacrenier N., Effect of sex on muscular development of Muscovy ducks, Reprod. Nutr. Dev. 39 (1999) 675-682.

[5] Beccavin C., Chevalier B., Simon J., Duclos M. Circulating insulin-like growth factors (IGF-I and -II) and IGF binding proteins in divergently selected fat or lean chickens: effect of prolonged fasting, Growth Horm. IGF Res. 9 (1999) 187-194.

[6] Burke W.H., Shultz F.T., Bielfelt S.W., The role of plasma growth hormone, prolactin, triiodothyronine and tetraiodothyronine in the regulation of growth and sex differences in body weight of turkeys, Growth Dev. Aging 58 (1994) $167-185$. 
[7] Capdevielle M.C., Scanes C.G., Effect of dietary acid or aluminium on growth and growth-related hormones in mallard ducklings, Arch. Environ. Contam. Toxicol. 29 (1995) 462-468.

[8] Cogburn L.A., Burnside J., Scanes C.G., Physiology of growth and development, in: Whittow G.C. (Ed.), Avian Physiology, Academic Press, London, England, 1999, pp. 635-649.

[9] Farhat A., Chavez E.R., Effects of line, dietary protein, sex, age and feed withdrawal on insulinlike growth factor-I in white Pekin ducks, Poult. Sci. 78 (1999) 1307-1312.

[10] Foltzer C., Harvey S., Mialhe P., Somatostatinlike immunoreactivity in duck plasma, hypothalamus and neural lobe during post-hatch growth: comparison with plasma and pituitary growth hormone concentrations, J. Endocrinol 113 (1987) $57-63$

[11] Gabarrou J.F., Geraert P.A., Williams J., Ruffier L., Rideau N., Glucose-insulin relationships and thyroid status of cockerels selected for high or low residual food consumption, Br. J. Nutr. 83 (2000) 645-651.

[12] Gatford K.L., Egan A.R., Clarke I.J., Owens P.C., Sexual dimorphism of the somatrotrophic axis, J. Endocrinol. 157 (1998) 373-389.

[13] Guémené D., Bédécarrats G., Garreau-Mills M., Zadworny D., Ontogeny of prolactin and $\mathrm{GH}$ secretions in turkey embryos, 1 st Int. Conf. Bird Reprod., Tours, France, 22-24 September, 1999 , pp. 2.

[14] Johnson R.J., Mc Murtry J.P., Ballard F.J., Ontogeny and secretory patterns of plasma insulin-like growth factor-I concentrations in meat-type chickens, J. Endocrinol. 124 (1990) $81-87$.
[15] Leclercq B., Croissance et composition corporelle du canard de Barbarie, in: Sauveur B., De Carville H. (Eds.), Le canard de Barbarie, INRA, Paris, France, 1990, pp. 23-39.

[16] Proudman J.A., Wentworth B.C., Radioimmunoassay of turkey growth hormone, Gen. Comp. Endocrinol. 36 (1978) 194-200.

[17] SAS/STAT user's guide, SAS Institute Inc., Cary, NC, 1989.

[18] Sauveur B., Origines et performances comparées du canard de Barbarie et du canard commun de race Pékin, in: Sauveur B., De Carville H. (Eds.), Le canard de Barbarie, INRA, Paris, France, 1990, pp. 3-11.

[19] Scanes C.G., Marsh J., Decuypere E., Rudas P., Abnormalities in the plasma concentrations of thyroxine, triiodothyronine and growth hormone in sex-linked dwarf and autosomal dwarf White Leghorn domestic fowl, J. Endocrinol. 97 (1983) $127-135$.

[20] Scanes C.G., Harvey S., Marsh J.A., King D.B., Hormones and growth in poultry, Poult. Sci. 63 (1984) 2062-2074.

[21] Scanes C.G., Radecki S.V., Aramburo C., Growth hormones and growth factors in avian development, Poult. Avian Biol. Rev. 7 (1996) 89-98.

[22] Stewart P.A., Washburn K., Variation in growth hormone, triiodothyronine (T3) and lipogenic enzyme activity in broiler strains differing in growth and fatness, Growth 47 (1983) 411-425.

[23] Vasilatos-Younken R., Scanes C.G., Growth hormone and insulin-like growth factors in poultry growth: required, optimal or ineffective?, Poult. Sci. 70 (1991) 1764-1780. 